\title{
Fish preservation: a multi-dimensional approach
}

\begin{abstract}
Fish is one of the most nutritionally valuable and highly perishable food stuffs. The delicacy of fish can be easily noticed from its rapid quality deterioration immediately after harvest, if held improperly and not processed promptly. The natural composition of fish and the contaminations they encounter during the processing are the main causes for the onset and subsequent undesirable quality changes in these commodities. The spoilage patterns of fish are broadly categorized as enzymatic, chemical and microbiological. The growth of pathogenic microorganisms as a result of contamination mostly does not produce detectable changes in the sensory qualities of fish, which adds to the challenge of fish processing. Thus, a number of preservation mechanisms have been and are being developed to tackle the quality and safety problems associated with fish and fishery products. Although every method can produce effective results, yet there is no single best method capable of ensuring the safety as well as halt the progress of spoilage at the same time. The various preservation methods used in the fish and fishery industry can be categorized into three as physical, chemical and bio-preservation methods. These methods have different modes of actions and are applied to extend the shelf life of fish and fishery products. The present review article provides an overview of some of the physical, chemical and biological preservation methods applied to fish and fishery products.
\end{abstract}

Keywords: fish preservation, fish quality and safety, fish spoilage, microbial safety and stability, shelf life extension, physical preservation, chemical preservation, hurdle technology
Volume 6 Issue 3 - 2018

\author{
Abdu Mahmud, ${ }^{1,2}$ Bereket Abraha, ${ }^{1,2}$ Melake \\ Samuel, ${ }^{2,3}$ Hamada Mohammedidris, ${ }^{2}$ Winta \\ Abraham, ${ }^{2}$ Elham Mahmud ${ }^{4}$ \\ 'School of Food Science and Technology, Jiangnan University, PR \\ China \\ ${ }^{2}$ Department of Marine Food and Biotechnology, Massawa \\ College of Marine Science and Technology, Eritrea \\ ${ }^{3}$ Food and Commodity Quality Management Department, \\ Russian State Agrarian University, Russia \\ ${ }^{4}$ School of Public Health, Asmara College of Health Sciences, \\ Eritrea
}

Correspondence: Abdu Mahmud, School of Food Science and Technology, Jiangnan University, Wuxi, China, Tel +86-15606160100 , Fax +86-510-85809610

Email abdumahmud87@gmail.com

Received: April 08, 2018 | Published: June 15, 2018

\section{Introduction}

The world population is growing drastically and thus, the demand for food has been increasing likewise. In the modern era, the awareness on the benefits of consuming nutritious food has made the demand for certain nutritious food stuffs, such as fish, to rank at the top of the highly demanded food stuffs. According to FAO, ${ }^{1}$ global seafood consumption has increased dramatically from $9.9 \mathrm{~kg}$ per capita in the 1960 s to $20 \mathrm{~kg}$ in 2016 . In addition to this, the exports of fishery products in developing countries deposited an income of $\$ 80$ billion and were estimated to be $\$ 148$ billion on world scale exports in 2014 .

The biochemical composition of live fish differs from species to species. Within the same species also their chemical composition differs depending on different factors such as, feed intake, migratory swimming and sexual changes in connection with spawning. Despite these variations, fish has proved to be one of the most nutritious food stuffs providing $20 \%$ of the protein intake of one third of the world's population $^{2}$ and is also the source of health-friendly oils, omega-3 $(\omega-3)$ polyunsaturated fatty acids (PUFAs). Moreover, they are a rich source of a number of micronutrients like, vitamin $\mathrm{D}$ and different minerals, which can be found in higher quantities in aquatic animals than in mammalian meats and plants.

However, fish is also known for its high perishability nature. The rapid deterioration of quality of fish and other seafoods after their harvest is mainly due to the various mechanisms of spoilage that takes place. The spoilage mechanisms associated with such deteriorations are grouped into microbial metabolic activities, endogenous enzymatic activities and chemical oxidation of lipids, all of which shorten the shelf life of seafoods. According to Gram and Huss, ${ }^{4}$ the high composition of non-protein nitrogen compounds and low acidity $(\mathrm{pH}>6)$ of the flesh of seafoods are the major cause of their spoilage, as these condition favor the growth of spoilage microorganisms. These microbes in turn produce metabolites that affect the organoleptic properties of the products and render them undesirable attributes.
Similarly, autolytic activities by endogenous enzymes of seafoods also results in products that initially cause loss of the characteristic fresh odor and taste of fish and then softens the flesh. These changes start short after the death of seafood animals and progresses to produce a number of volatile compounds which give the products their spoilage characteristics. The details of the mechanism of such changes have been described by several authors..$^{5-7}$ These enzyme driven changes are often accompanied by microbial metabolic activities.

Chemical oxidation of lipids is a common spoilage pattern in fatty fish in particular. This spoilage pattern depends mainly on the presence of oxygen which is responsible for the oxidative rancidity of the polyunsaturated fatty acids of fish and fishery products. ${ }^{5}$

Even though the spoilage patterns of fish can be explained as three distinct groups, all the mechanisms progress simultaneously, speeding up the overall spoilage of the products. As already noted, the spoilage mechanisms can be driven by microbial growth, enzymatic activities or chemical reactions. Thus, the preservation methods intended to stop the various spoilage patterns are expected to target these three causes in different approaches.

Improper handling and processing of seafoods, including fish, can lead to its contamination and subsequent growth of pathogenic microorganisms. In addition, the natural occurrence of aquatic biotoxins and natural pathogenic flora of the aquatic environment also contribute to seafood borne diseases. Huss et al., ${ }^{8}$ have classified seafoods into seven groups based on their risk of microbial contamination and the processing method undergone. Generally, processing mainly controls microbiological hazards but leaves chemical hazards or biotoxins virtually unaffected. Effective control of chemical hazards and biotoxins has to be applied mostly during primary production and the pre-harvest stages. ${ }^{9}$

The present article provides a brief overview of different preservation methods applied to fish and fishery products by 
categorizing them into three broad groups; physical, chemical, and microbiological methods.

\section{Physical methods of fish preservation}

The physical methods of fish preservation can be described as three distinct spoilage control measures, namely: moisture control, thermal control and non-thermal control technologies.

\section{Moisture control measures}

Drying: The availability of water or moisture is a critical need for microbial metabolism and growth. The free water available in the matrix of foods that support the growth of microorganisms is termed as water activity $\left(a_{w}\right)$. High $a_{w}$ level is required for the growth of most microorganisms. The $\mathrm{a}_{\mathrm{w}}$ level of different microorganisms is different, majority of the bacterial species being the top based on their requirements for the highest levels (Table 1) and thus, are the main contributors of fish quality deteriorations. On the other hand, fish and fishery products are known for their high moisture content in their fresh status (Table 2) which makes them conducive environments for microbial proliferation. Thus, drying and curing are the oldest, simplest and widely used preservation methods intended to control the moisture content of food stuffs by lowering their $\mathrm{a}_{\mathrm{w}}$.

Table I Minimum values of water activity for microbial growth ${ }^{10}$

\begin{tabular}{ll}
\hline Microorganisms & Water activity $\left(\mathrm{a}_{\mathrm{w}}\right)$ \\
\hline Bacteria & 0.91 \\
Yeasts & 0.85 \\
Moulds & 0.8 \\
Halophilic bacteria & 0.75 \\
Xerophilic bacteria & 0.65 \\
Osmophilic bacteria & 0.6
\end{tabular}

Table 2 Chemical composition of the fillets of various fish species ${ }^{13-15}$

\begin{tabular}{|c|c|c|c|}
\hline Species & Scientific name & Water\% & Lipid\% \\
\hline Blue whiting & Micromesistius poutassou & $79.0-80.0$ & $1.9-3.0$ \\
\hline Cod & Gadus morhua & $78.0-83.0$ & $0.1-0.9$ \\
\hline Eel & Anguilla anguilla & $60.0-71.0$ & $8.0-31.0$ \\
\hline Herring & Clupea harengus & $60.0-80.0$ & $0.4-22.0$ \\
\hline Plaice & Pleuronectes platessa & 81.0 & I.I-3.6 \\
\hline Salmon & Salmo salar & $67.0-77.0$ & $0.3-14.0$ \\
\hline Trout & Salmo trutta & $70.0-79.0$ & $1.2-10.8$ \\
\hline Tuna & Thunnus spp. & 71.0 & 4.1 \\
\hline $\begin{array}{l}\text { Norway } \\
\text { lobster }\end{array}$ & Nephrops norvegicus & 77.0 & $0.6-2.0$ \\
\hline Pejerrey & Basilichthys bornariensis & 80.0 & $0.7-3.6$ \\
\hline Carp & Cyprinus carpio & 81.6 & 2.1 \\
\hline Sabalu & Prochilodus platensis & 67.0 & 4.3 \\
\hline Pacu & Colossoma macropomum & 67.1 & 18.0 \\
\hline Tambaqui & Colossoma brachypomum & 69.3 & 15.6 \\
\hline Chincuina & Pseudoplatystoma tigrinum & 70.8 & 8.9 \\
\hline Corvina & Plagioscion squamosissimus & 67.9 & 5.9 \\
\hline Bagre & Ageneiosus spp. & 79.0 & 3.7 \\
\hline
\end{tabular}

The principle of drying preservation method is to remove water from the food matrix and thus, lower the $\mathrm{a}_{\mathrm{w}}$ of foods, which in turn arrests microbial activity. The method proved to be effective in extending the shelf life of fishery products. However, if the drying process is not carried out properly, i.e., if the drying is too rapid, it might result in layer hardening (hard texture) and thus affects the palatability feature of the product undesirably. On the other hand if the drying process is slow, undesirable microbes might survive and grow. Drying methods that depend on high temperature treatment have been found to trigger lipid oxidation and result in off flavored fish products. ${ }^{11}$ According to Horner, ${ }^{12}$ three types of drying are used for fish preservation, namely, air or contact drying, vacuum drying and freeze drying.

Sun drying is the simplest and cheapest method of air drying process used for foods. It can be done as open sun drying or solar tent drying. Effective open sun drying depends mainly on the environmental temperature, relative humidity and wind speed. However, products dried using this method, are subjected to insects' and birds infestations.

An alternative method, solar tent drying has been suggested by Doe et al. ${ }^{16}$ The design of the tent drier (Figure 1) is more effective than open sun drying due to its enclosed structure that absorbs and traps heat inside by the help of black-painted rocky stones and effectively uses it both during the day and night. The design is simple and economically feasible to be used in the developing countries. ${ }^{17}$

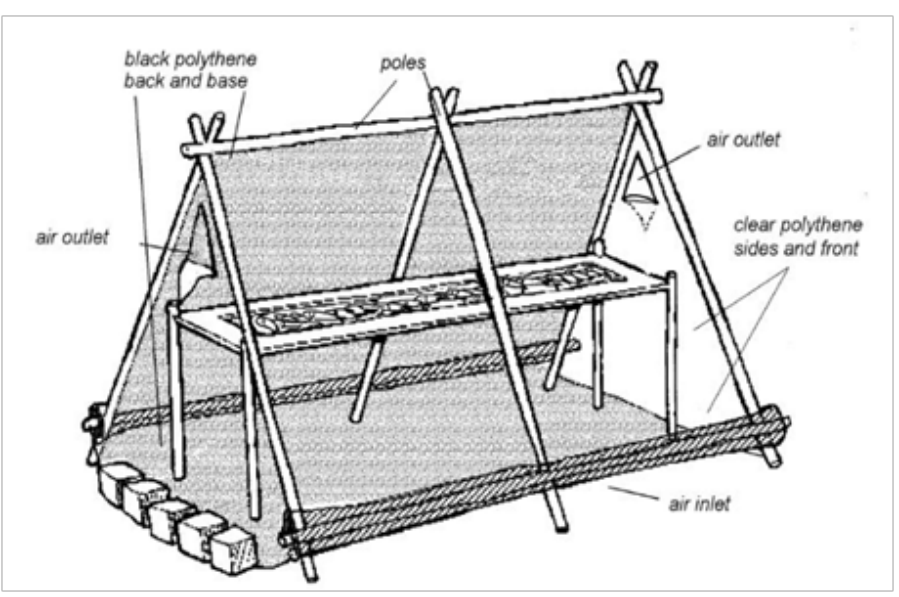

Figure I Solar tent drier (Adapted from Doe et al. ${ }^{16}$ ).

\section{Thermal control}

Low temperature treatments are the methods used immediately on board following the harvest of aquatic products. Chilling in various forms including, wet ice, refrigerated seawater (RSW), chilled seawater (CSW), solid and liquefied forms of carbon dioxide $\left(\mathrm{CO}_{2}\right)$, liquid nitrogen, and chill air have been reported by several authors. It has been recommended by $\mathrm{FAO}^{18}$ that fish should be cooled to chilling temperature $\left(0^{\circ} \mathrm{C}\right)$ immediately after capture. According to Olley \& Ratkowsky, ${ }^{19}$ the preservative effect of chilling is due to its ability to reduce the growth rate of spoilage microorganisms and their metabolic activities and thus maintains the post-harvest quality changes to the minimum. Such treatments can extend the shelf life of fish and fishery products only for days, as certain endogenous autolytic enzymes and proteolytic enzymes produced by contaminant microbes can deteriorate the quality in a short-run. 
In RSW, the product is cooled to a temperature much lower than the melting ice treatment. This is due to the reduced freezing point of seawater attributed to the presence of salts. Thus, RSW has been used as a better option for chilling operations onboard of fishing vessels for its greater cooling rate, reduced pressure and physical damage on fish, less exposure to oxygen as well as more rapid handling of large quantities of fish with little delay or labor involvement, and in many cases, an extended shelf life. ${ }^{20}$ However, the high chance of spread of spoilage microbes in the circulating water, excessive uptake of salt, uptake of water by low fat species, loss of protein and problems with anaerobic bacteria are non-negligible drawbacks of RSW systems.

Freezing has been used as a long term preservation technique for decades. Fish and other meat foods were reported to keep for months under proper frozen storage. The treatment retards microbial growth and enzymatic activity in fish to a greater extent when compared to chilling and thus, preserves the flavor and nutritional properties better. ${ }^{21}$ However, the formation of ice crystals during freezing has been observed to affect the quality of frozen products. With the formation of large crystals, textural damage and membrane disruption with subsequent oxidation has been reported by Alizadeh et al. ${ }^{21}$

Non-thermal control: Non-thermal physical preservation approaches employed in the seafood industry include: high pressure processing, packaging technologies, irradiation, ozonation, as well as pulsed electric fields and oscillatory magnetic fields treatments. Of these, there are insufficient reports on the preservative potential and suitability of the latter two in their use on fish and fishery products. The term advanced oxidation process is often used to describe treatments such as, ozonation and ultraviolet (UV) irradiations, to refer to the processes that involve oxidation processes used to eliminate inorganic and organic contaminants and/or pollutants with the help of reactive free radicals produced by ozone $\left(\mathrm{O}_{3}\right)$, hydrogen peroxide $\left(\mathrm{H}_{2} \mathrm{O}_{2}\right)$, titanium oxide $\left(\mathrm{TiO}_{2}\right)$, zinc oxide $(\mathrm{ZnO})$, and $\mathrm{UV}$ radiations. ${ }^{22}$

High pressure treatments: High pressure treatments have almost same effect on microorganisms and enzymes as high temperature treatments. These technologies are based on the observation that microorganisms are inactivated due to lethal structural and biochemical alterations caused to the cells as a result of residence under such high pressures. Moreover, the cell deformation and damage associated with high pressure treatments were reported to be reversible with treatments in the range of $100-300 \mathrm{Mpa} .^{23}$ However, these treatments fail to inactivate resistant bacterial spores. Such spores require pressure treatments as high as $1200 \mathrm{MPa}$ for their inactivation. ${ }^{23}$

Several authors have reported the pros and cons of such treatment and supported their statements with findings. Riz et al., ${ }^{24}$ have reported on the synergistic effect of high pressure treatment at $200 \mathrm{MPa}$ and sub-zero temperature treatment to have inhibitory effect on Listeria monocyogenes in smoked salmon. They have also observed lightening of color and toughening of texture of the product as undesirable outcomes. Similarly, Matejková et al., ${ }^{25}$ reported on the possibility of shelf life extension of vacuum-packed trout exposed to high pressure treatment stored at $3.5^{\circ} \mathrm{C}$, from 5-6 days to $21-28$ days, in reference to the reduced content of biogenic amines observed on the treated product. On the contrary, pressure treatments resulted in bright and dull red appearance in species as turbot, ${ }^{26}$ sheep head, ${ }^{5} \operatorname{cod}^{27}$ and carp. $^{28}$

Another study carried by Yagiz et al., ${ }^{29}$ the effect of high pressure processing on the quality of rainbow trout and mahi was investigated.
The study used a standard laboratory scale unit with a pressurization chamber of 2.5 liters volume capacity. The treatment was done at a pressure range of $150-600 \mathrm{MPa}$. The results obtained indicated that treatment of $300 \mathrm{MPa}$ for rainbow trout and $450 \mathrm{MPa}$ for mahi were the optimum levels to control microbial load, lipid oxidation and color changes.

Ozonation: Ozone has been studied for its potential in disinfecting and improving the sensory quality of seafoods. Gonçalves ${ }^{30}$ stated that antimicrobial effect of ozone depends on its concentration, contact time, temperature and the production system used. According to Gonçalves, ${ }^{30}$ low concentrations of ozone in solutions can decrease the half-life of ozone and thus weakening its bacteriocidal effect.

In a study conducted by Mendonça et al., ${ }^{31}$ treatment of whole fresh water tilapia with $1.5 \mathrm{ppm}$ ozonated water for $15 \mathrm{~min}$ was sufficient to result in $88.25 \%$ reduction of initial microbial load. The same study also reported a reduction of $77.2 \%$ and $79.49 \%$ of microbial load in fillets of the same fish species treated with ozonated water at concentrations of 1 and $1.5 \mathrm{ppm}$ respectively. The results were obtained with no $\mathrm{pH}$ and color alterations of the fillets. However, initiation of lipid oxidation process was detected in reference to increased thiobarbituric acid reactive substances assay (TBARS) values.

Irradiation: Irradiation in foods is described in three different ways that do not involve heat treatments. Radurization (cold pasteurization) involves the use of low doses $(<1 \mathrm{kGy})$ which inactivates non-spore forming bacteria. Radicidation reduce the number of viable and nonspore forming pathogenic bacteria and parasites using intermediate doses (2-8kGy). Radappertization (cold sterilization) is used to eliminate highly pathogenic bacteria such as, Clostridium botulinum at high doses $(>10 \mathrm{kGy}) .{ }^{32}$

Irradiation doses of 1.0 to $2.0 \mathrm{kGy}$ has been suggested by Matches \& Liston $^{33}$ for the effective elimination of contaminant micro-organism in raw fish and seafood dishes. Low dose irradiation has also proved to be effective for fish preservation when applied in combination with chilling or heating processes. ${ }^{34}$ However, the destruction of large populations of bacterial spores requires high doses of radiation. Sikorski \& Sun $\operatorname{Pan}^{35}$ stated that even medium doses of 4-10kGy can induce undesirable sensor changes, mainly off flavors in fish and fishery products. Thus, irradiation processes fail to achieve both, complete elimination of all types of microorganisms and maintain sound organoleptic characteristics at the same time.

Packaging technologies: Packaging technologies involving either the replacement of air by certain gases (such as, $\mathrm{CO}_{2}, \mathrm{O}_{2}, \mathrm{~N}_{2}$ or combination of all) or removal of air and thus reducing the headspace to possible minimum has been used in the preservation of muscle and plant foods. Such packages are often termed as modified atmosphere packaging (MAP) and vacuum packaging (VP). The use of packaging material with low gas and water permeability is very crucial in such technologies in order to prevent the exchange of gases between the interior and exterior of the packaged product and thus maintain the right atmospheric conditions around the product.

The preservative effect of such technology is based on the atmospheric condition they create around the product. This condition establishes a significant hurdle for most strictly aerobic and facultative spoilage microorganisms. Moreover, lipid oxidation can also be prevented to some extent. Anon ${ }^{36}$ recommended that the retail pack for lean fish and shell fish to be composed of a mixture of $\mathrm{CO}_{2}: \mathrm{N}_{2}: \mathrm{O}_{2}$ 
in a ratio of (40:30:30) and $\mathrm{CO}_{2}: \mathrm{N}_{2}(60: 40)$ for fatty and smoked fish. The gas:product ratio of MAP packed fish is also recommended to be in the range of $2: 1-5: 1$, where $\mathrm{CO}_{2}$ concentration can be maintained between $20-100 \% .37$

\section{Chemical methods of fish preservation}

\section{Curing}

The term curing is referred to the addition of salt, sugar, nitrites, nitrates, seasonings or spices and phosphates to preserve food stuff. In addition to preservation, this particular processing can result in a characteristic color and flavor of the cured products. Salt has been the most widely used ingredient for curing of meat foods. Its main antimicrobial mode of action is creating a low $\mathrm{a}_{\mathrm{w}}$ environment in the food which forces microorganisms to experience prolonged lag phase and eventually enter the death phase.

Although this preservation method is one of the oldest and simplest fish preservation methods, the growth of halophilic and halotolerant microorganisms cannot be arrested and often their growth produce white patches on the fish fillets. Moreover, salting has also been reported to be as a pro-oxidant agent in several meat and seafood products. ${ }^{38-39}$ Yet, few reports support the neutral effect of salt on lipid oxidation $^{40-41}$ and as antioxidant. ${ }^{42}$

Smoking: Smoking is a means of chemical preservation applied to meat foods. Although the process involves heat treatment to some extent, the preservative weight is attributed to its chemical products. It has been reported that smoking has both antimicrobial and antioxidant effects. Varlet et al., ${ }^{43}$ has reported that the combined effect of phenolic compounds produced during smoking process and the high temperature condition result in reduced microbial growth and oxidation. Moreover, carbonyl compounds produced during the process can contribute to the characteristic color, texture and fishy odor of the product. ${ }^{44}$ Thus, the preservation objectives of smoking include, surface drying which acts as a barrier for microbial invasions; reduces water activities resulting from the pretreatment process with salt; deposition of phenolic compounds which aid in delaying autoxidation of fish lipids and deposition of antimicrobial substances (such as, aldehydes, ketones, alcohols, acids, hydrocarbons, esters, phenols, ethers, etc.).

Two methods of smoking are practiced for fishery products, cold smoking and hot smoking, depending on the temperature used. Products treated with cold smoking is carried out at around $30^{\circ} \mathrm{C}$ following salting and drying treatment of fish muscle. ${ }^{45}$ Smoked salmon is a common product prepared by this treatment and eaten raw. Hot smoking on the other hand, involves treatment at a temperature range of $70-80^{\circ} \mathrm{C}$ and results in cooked product that do not require subsequent processing. ${ }^{46}$ Although smoked lean fish are preserved longer compared to fatty fish, fumigation, storage temperature and salt content, are determinant factors of the shelf life of smoked products. Several reports have been produced on the effect of smoking on various fish species (Table 3). Details of the smoking method and its mode of actions are described by Varlet et al., ${ }^{44}$ Varlet et al. ${ }^{43} .{ }^{47-50}$ Many authors ${ }^{51-54}$ have suggested the use of smoking in combination of one or more preservation method for highly effective results.

Table 3 Examples of smoked fish products investigated by different authors

\begin{tabular}{llll}
\hline Species & Smoking process & Product & References \\
\hline Trout (gutted, split) & Cold/hot & Smoked trout & 56 \\
Eel (gutted) & Cold/hot & Smoked eel & 57 \\
Salmon (gutted, split) & Cold & Smoked salmon & 58 \\
Mackerel (fillets) & Hot & Smoked mackerel & 59 \\
Herring (fillets) & Cold & Kipper fillets & 60 \\
Haddock & Cold & Haddock & 43 \\
\hline
\end{tabular}

The traditional smoking process is carried out by direct exposure of foods to smoke. However, such treatments can lead to the accumulation of harmful substances (such as, polycyclic aromatic hydrocarbons (PAHs)) which result from incomplete combustion of wood. These compounds have potential adverse effects on human health. Moreover, Munasinghe et al., ${ }^{55}$ have reported the high possibility of uneven distribution of volatile compounds on the fish flesh treated by direct exposure to smoke, which can affect the quality of the end product undesirably.

\section{Natural antimicrobial preservatives}

Naturally occurring antimicrobial substances such as essential oils (EOs) and extracts of various plants, spices, and herbs are reported to have effective activity against a number of pathogenic and spoilage microorganisms associated with foods. ${ }^{61}$ A comprehensive detail of major components of EOs including, carvacrol, thymol, g-terpinene and $\mathrm{p}$-Cymene (oregano and thyme), a-pinene, bornyl-acetate, camphor and 1,8-cineole (rosemary), eugenol and eugenyl acetate (clove, etc.) has been reviewed by Burt. ${ }^{62}$ These natural extracts have been incorporated in the packaging materials as well as edible films and coatings to enhance the keeping quality of minimally processed and delicate foods such as meat, fish and fruits. ${ }^{63-65}$

In a study carried out by Fernandez Saiz et al., ${ }^{66}$ the antimicrobial activity of chitosonium acetate films on Salmonella spp., Staphylococcus aureus and Listeria monocytogenes showed a direct correlation with the film weight, i.e., cell viability was reduced completely when high amounts of film (40-80mg) were used. However, the antimicrobial effect of the film was found to be lower in the fish soup compared to the results obtained in TSB culture media, although the use of the film did neither affect the sensory properties nor the $\mathrm{pH}$ of the soup. Similarly, Tsai et al. ${ }^{67}$ investigated the effect of chitosan films on fish spoilage microbes and reported an improvement of shelf life of treated fishery product from 5 to 9days. Several other authors ${ }^{68-69}$ have studied the biocide mode of action of this polysaccharide in great details and reported satisfactory results.

According to the findings of Iturriaga et al., ${ }^{70}$ the antimicrobial activity of citrus extract (water soluble extract) and the EOs, oregano 
and thyme were evident (Table 4). Their findings were illustrated as the antimicrobial activities of these substances tested against Listeria innocua (surrogate of Listeria monocytogenes), Pseudomonas fluorescens (dominant spoilage bacterium in fishery products) and Aeromonas hydrophila. Though the three proved to be effective, the authors suggested that citrus extract to be the best option to incorporate into three biopolymers gelatin, methyl cellulose and their $(50: 50 \mathrm{w} / \mathrm{w})$ blend to produce edible film for its odorless and water solubility properties as well as highest antimicrobial activity.

Table 4 Minimum inhibitory concentration (MIC) obtained by disc diffusion method for the three active extracts against the tested bacteria (Adapted from Iturriaga et al. ${ }^{70}$ )

\begin{tabular}{lllll}
\hline \multirow{2}{*}{ Extract } & Temperature & \multicolumn{2}{l}{ MIC $(\mu \mathrm{ll} / \mathrm{ml})^{\mathrm{a}}$} & \\
\cline { 3 - 5 } & & L. innocua & P. fluorescens & A. hydrophila \\
\hline \multirow{2}{*}{ Citrus extract } & $\mathrm{T}_{\mathrm{opt}}^{\mathrm{b}}$ & $2.5 \pm 0.0$ & $40.0 \pm 0.0$ & $10.0 \pm 0.0$ \\
& $4^{\circ} \mathrm{C}$ & $1.3 \pm 0.0$ & $26.7 \pm 11.5$ & $6.7 \pm 2.9$ \\
\multirow{2}{*}{ Oregano EO } & $\mathrm{T}_{\mathrm{opt}}{ }^{\mathrm{b}}$ & $5.0 \pm 0.0$ & $5.0 \pm 0.0$ & $2.5 \pm 0.0$ \\
& $4^{\circ} \mathrm{C}$ & $5.0 \pm 0.0$ & $9.7 \pm 2.9$ & $2.5 \pm 0.0$ \\
\multirow{2}{*}{ Thyme EO } & $\mathrm{T}_{\mathrm{opt}}{ }^{\mathrm{b}}$ & $5.0 \pm 0.0$ & $5.0 \pm 0.0$ & $2.5 \pm 0.0$ \\
& $4^{\circ} \mathrm{C}$ & $4.2 \pm 1.4$ & $5.0 \pm 0.0$ & $2.5 \pm 0.0$ \\
\hline
\end{tabular}

a Values given as Mean \pm SD $(n=3)$

${ }^{b} T_{\text {opt }}$ : optimal growth temperature. $37^{\circ} \mathrm{C}$ for L. innocua, $30^{\circ} \mathrm{C}$ for P. fluorescens and A. hydrophila

Some finding have revealed that the effectiveness of such antimicrobial substances also depend greatly on temperature. Bagamboula et al., ${ }^{71}$ suggested that microorganisms tend to be more susceptible to antimicrobials at exposure temperatures close to their optimal due to their increased metabolic activity. Their suggestion was based on their observations on higher reductions in the population of Shigella spp. When treated at $22^{\circ} \mathrm{C}$ than at $7^{\circ} \mathrm{C}$. On the other hand, the combined effect of more than one natural extract was found to be more effective than their single use. Ilhak $\&$ Guran $^{72}$ have concluded that a combination of $0.1 \%$ thymol and $2 \%$ sodium lactate showed a synergistic effect on Salmonella Typhimurium on days 3 and 5 of storage of fish patty, although the sole use of $2 \%$ sodium lactate showed significant inhibition against Listeria monocytogenes than the aforementioned treatment. A number of other natural antimicrobial compounds have been investigated by Cheng et al., ${ }^{73}$ Rubén et al., ${ }^{74}$ Speranza et al., ${ }^{75}$ Ortiz-Viedma et al., ${ }^{76}$ Raeisi et al. ${ }^{77}$

Organic acids: Organic acids and their salts have also been reported to have positive impact on the safety and quality of food products. According to Sallam, ${ }^{78}$ the growth of spoilage flora and lipid oxidation of salmon fillets packed in polyvinylidene film were maintained at the lowest pace for 15 days at $1{ }^{\circ} \mathrm{C}$ when treated with $2.5 \%(\mathrm{w} / \mathrm{v})$ aqueous solution of sodium acetate, sodium lactate, or sodium citrate dip for 10 minutes at $4^{\circ} \mathrm{C}$. Similarly, cold smoked salmon brine injected

Table 5 Bacteriocins produced by LAB (Adapted from Hall ${ }^{83}$ ) with potassium lactate and sodium acetate were observed to inhibit the growth of $L$. monocytogenes at a storage temperature of $4^{\circ} \mathrm{C}$ for 32 days. ${ }^{79}$ The same results were also reported on the same product and treatment stored at $10^{\circ} \mathrm{C}$ in vacuum package for 42 days. ${ }^{80}$

\section{Microbiological methods of fish preservation}

This is a method of tackling the growth of undesirable microorganisms by favoring the growth of competitive and antagonist (to the undesirable microbes) in a food product. The phenomenon is often termed "biopreservation". In this method, either the bacterium or the metabolite it produces, play the role preservation. Lactic acid bacteria $(\mathrm{LAB})$ are the most widely studied and dealt with in the area.

$\mathrm{LAB}$ are not considered as indigenous microbes of the aquatic environment nor aquatic animals. But, many species (such as Lactobacillus spp., Carnobacterium spp., Aerococcus spp., Enterococcus spp., Lactococcus spp., etc.) are also reported to be associated with different fish products. The preservative action of $\mathrm{LAB}$ is attributed to either their competition with the undesirable microbes for nutrients or the antimicrobial metabolites they produce or both. ${ }^{81} \mathrm{~A}$ list of biopreservation studies made on fish by different authors is given in a review article authored by Ghanbari et al..$^{82}$ Table 5 illustrates some of the bacteriocins produced by LAB species and their target organisms. ${ }^{83}$

\begin{tabular}{lll}
\hline Bacteriocin & Produced by & Active against \\
\hline Nicin(s) & Lc lactis subspp lactis & Bacillus cereus; Clostridium botulinum; Staphylococcus aureus \\
Pediocin(s) & P acidilactis & Listeria monocytogenes; Clostridium sporogenes \\
Reuterins & Lb reuteri & Listeria monocytogenes; Salmonella typhimurium; Shigella spp \\
\hline
\end{tabular}

The use of live microbial antagonists (biopreservatives) is suggested to follow certain criteria and requirement for safety reasons ${ }^{84}$ In addition to their desired antagonistic effect against a wide spectrum of spoilage and pathogenic microorganisms as well as their capability to withstand varying processing technologies and storage conditions, these protective cultures should not pose any adverse health effect (i.e., they should be safe) and also neither them nor their metabolites should affect the sensory, chemical and physical properties of the end product in a way that confer the product with unattractive characteristics. ${ }^{85-86}$ 


\section{Hurdle technology of fish preservation}

Almost all preservation methods reveal poor effect when used individually. It might also require their use at the highest concentration or intensity, which in turn can result in sensorial and nutritional deterioration of the product. Leistner ${ }^{87}$ has suggested the use of more than one preservative factor (hurdle) to keep undesirable microbes in a hostile environment, which inhibits their growth and leads them to death. The principle of the technology involves the use of more than one hurdle at mild levels and subjects the microorganisms to multi-stress reactions by disturbing their homeostasis. This unstable homeostasis condition eventually results in their metabolic exhaustion and death.

\section{Conclusion}

The causes of quality deterioration in fish and fishery products are numerous. The preservation methods suggested to combat every cause are also different. The challenge of the preservation of such delicate and nutritious product is also noted to be multi-dimensional with no absolute or ideal preservation method capable of tackling the varying deterioration causes and relieving the tension of the challenge. It is a dynamic area in the science of food, which will keep introducing innovative technologies with the progress of technological developments.

\section{Acknowledgements}

We would like to acknowledge our respective institutes for providing us with access to various databases from their archives and from the internet. We would also like to express our appreciation to the FAO for granting us to access their database (AGORA).

\section{Conflict of interest}

The authors hereby, declare that there is no conflict of interest in publishing this article.

\section{References}

1. Food and Agriculture Organization (FAO). Global per capita fish consumption rises above 20kilograms a year. Italy; 2016.

2. Béné C, Macfayden G, Allison EH. Increasing the contribution of small scale fisheries to poverty alleviation and food security. Italy: FAO Fisheries Technical guidelines for responsible fisheries; 2007.

3. Mohanty BP, Mahanty A, Ganguly S, et al. Nutritional composition of food fishes and their importance in providing food and nutritional security. J Food Chemistry. 2017.

4. Gram L, Huss HH. Microbiological spoilage of fish and fish products. Int J of Food Microbiol. 1996;33(1):121-137.

5. Ashie INA, Smith JP, Simpson BK. Spoilage and shelf-life extension of fresh fish and shellfish. Crit Rev in Food Sci and Nutr. 1996;36(1-2):87121.

6. Huss HH. Quality and quality changes in fresh fish. FAO Fisheries Technical Paper no. 348. 1995.

7. Boziaris IS, Kordila A, Neofitou C. Microbial spoilage analysis and its effect on chemical changes and shelf-life of Norway lobster (Nephrops norvegicus) stored in air at various temperatures. Int $J$ of Food Sci and Technol. 2011;46(4):887-895.

8. Huss HH, Reilly A, Embarek KB. Prevention and control of hazards in seafood. Food Control. 2000;11(2):149-156.
9. Boziaris IS. Seafood processing-technology, quality and safety. IFST advances in food science. John Wiley \& Sons. 2014. p. 1-7.

10. Burt JR. Fish smoking and drying: the effect of smoking and drying on the nutritional properties of fish. Elsevier Science Publishers Ltd. 1988. $166 \mathrm{p}$.

11. Cassens RG. Meat preservation: preventing losses and assuring safety. Food and Nutrition Press. USA;1994

12. Horner WFA. Preservation of fish by curing (drying, salting and smoking). In: Hall GM, editor. Fish processing technology. $2^{\text {nd }}$ ed. UK: Blackie Academic and Professional publishers; 1997. p. 32-73.

13. Murray J, Burt JR. The composition of fish. In: Huss HH editor. Quality and quality changes in fresh fish. Italy: FAO Fisheries Technical Paper no $348 ; 1969$.

14. Poulter NH, Nicolaides L. Studies of the iced storage characteristics and composition of a variety of Bolivian freshwater fish. 1. Altiplano fish. In: Huss HH editor. International journal of Food science \& technology. 1985;20(4):437-449.

15. Poulter NH, Nicolaides L. Studies of the iced storage characteristics and composition of a variety of Bolivian freshwater fish. 2. Parana and Amazon Basins fish. In: Huss HH editor. International journal of Food science \& technology.1985;20(4):451-465.

16. Doe PE, Ahmed M, Muslemuddin M, et al. A polyethylene tent dryer for improved Sun drying of fish. Food technology in Australia. 1977;29:437-441.

17. Abraha B, Samuel M, Mohammud A, et al. A comparative study on quality of dried anchovy (Stelophorus heterolobus) using open sun rack and solar tent drying methods. Turk $J$ of Fish and Aqu Sci. 2017;17:1107-1115.

18. Food and Agriculture Organization (FAO). Reduction of wastage in fisheries. Info Fish Int. 1997;3:14.

19. Olley J, Ratkowsky DA. Temperature function integration and its importance in the storage and distribution of flesh food above the freezing point. Food technol Australia. 1973;25(2):66-73.

20. Chang KL, Chang J, Shiau CY, et al. Biochemical, microbiological and sensory changes in sea bass (Lateolabrax japonicus) under partial freezing and refrigerated storage. J Agri Food Chem. 1988;46(2):682686.

21. Alizadeh E, Chapleau N, De Lamballerie M, et al. Effect of different freezing processes on the microstructure of Atlantic salmon (Salmo salar) fillets. Innov Food Sci Emerg Technol. 2007;8(4):493-499.

22. Gonçalves Alex A. Processos Oxidativos Avançados: Ozônio (Advanced Oxidation Processes: Ozone). In: Tecnologia do pescado: ciência, tecnologia, inovação e legislação (fish technology: science, technology, innovation and legislation); 2011.

23. Rastogi NK, Raghavarao K, Balasubramaniam VM, et al. Opportunities and challenges in high pressure processing of foods. Crit Rev Food Sci Nutr. 2007;47(1):69-112.

24. Ritz M, Jugiau F, Federighi M, et al. Effects of high pressure, subzero temperature, and $\mathrm{pH}$ on survival of Listeria monocytogenes in buffer and smoked salmon. J Food Prot. 2008;71(8):1612-1618.

25. Matejková K, Krížek M, Vácha F, et al. Effect of high-pressure treatment on biogenic amines formation in vacuum-packed trout flesh (Oncorhynchus mykiss). Food Chem. 2013;137(1-4):31-36.

26. Chevalier D, Le Bail A, Ghoul M. Effects of high pressure treatment (100-200MPa) at low temperature on turbot (Scophthalmus maximus) muscle. Food Res Int. 2001;34(5):425-429. 
27. Angsupanich K, Ledward DA. High pressure treatment effects on cod (Gadus morhua) muscle. Food Chem. 1998;63(1):39-50.

28. Sequeira MunozA, Chevalier D, Lebail A, et al. Physicochemical changes induced in carp (Cyprinus carpio) fillets by high pressure processing at low temperature. Innov Food Sci Emerg Technol. 2006;7(1-2):13-18.

29. Yagiz Y, Kristinsson HG, Balaban MO, et al. Effect of high pressure treatment on the quality of rainbow trout (Oncorhynchus mykiss) and mahi mahi (Coryphaena hippurus). J of Food Sci. 2007;72(9):C509C515.

30. Gonçalves Alex A. Ozone as a safe and environmentally friendly tool for the seafood industry. J of Aqua Food Prod Technol. 2015;25(2):210-229

31. De Mendonça Andressa MS, Gonçalves Alex A. Effect of aqueous ozone on microbial and physicochemical quality of Nile tilapia processing. $J$ Food Proc Pres. 2017;41(6):e13298.

32. Aymerich T, Picouet PA, Monfort JM. Decontamination technologies for meat products. Meat Sci. 2008;78:114-129.

33. Matches JR, Liston JB. Radiation destruction of Vibrio parahaemolyticus J of Food Sci. 1971;36(2):339-344.

34. Venugopal V, Doke SN, Thomas P. Radiation processing to improve the quality of fishery products. Crit Rev in Food Sci and Nutr. 1999;39(5):391-440.

35. Sikorski ZE, Sun Pan B. Preservation of seafood quality. In: Shahidi F, Richard Botta J, editors. Seafoods: chemistry, processing technology and quality. Chapman and Hall; 1994. p. 168-189.

36. Anonymous. Guidelines for the handling of fish packed in a controlled atmosphere. UK: Sea Fish Industry Authority. 1985

37. Randell K, Ahvenainen R, Hattula T. The effect of gas/product ratio and $\mathrm{CO}_{2}$ concentration on the shelf-life of MA packed fish. Pack Technol and Sci. 1995;8(4):205-218.

38. Kanner J, Harel S, Jaffe R. Lipid peroxidation of muscle food as affected by NaCl. J of Agri and Food Chem. 1991;39(6):1017-1021.

39. Overholt MF, Mancini S, Galloway HO, et al. Effects of salt purity on lipid oxidation, sensory characteristics, and textural properties of fresh, ground pork patties. LWT-Food Sci and Technol. 2016;65:890-896.

40. Kong F, Oliveira A, Tang J, et al. Salt effect on heat-induced physica and chemical changes of salmon fillet (O. gorbuscha). Food Chem. 2008106(3):957-966.

41. Vara-Ubol S, Bowers JA. Effect of $\alpha$-tocopherol, $\beta$-carotene, and sodium tripolyphosphate on lipid oxidation of refrigerated, cooked ground turkey and ground pork. J of Food Sci. 2001;66(5):662-667.

42. Sakai T, Shimizu Y, Kawahara S. Effect of $\mathrm{NaCl}$ on the lipid peroxidation-derived aldehyde, 4-hydroxy-2-nonenal, formation in boiled pork. Biosci Biotechnol and Biochem. 2006;70(4):815-820.

43. Varlet V, Prost C, Sérot T. Volatile aldehydes in smoked fish: Analysis methods, occurrence and mechanisms of formation. Food Chem Anal Nutr and Clin Methods. 2007;105:1536-1556.

44. Varlet V, Knockaert C, Prost C, et al. Comparison of odor-active volatile compounds of fresh and smoked salmon. J of Agri and Food Chem. 2006;54(9):3391-3401.

45. Montero P, Gómez-Guillén MC, Borderias AJ. Influence of salmon provenance and smoking process on muscle functional characteristics. $J$ of Food Sci. 2003;68(4):1155-1160.

46. Bannerman AMcK. Hot smoking of fish. Torry research advisory note \#82. Torry Research Station. Aberdeen: Ministry of Agriculture, Fisheries and Food.

47. Varlet V, Prost C, Sérot T. Volatile aldehydes in smoked fish: Analysis methods, occurrence and mechanisms of formation. Food Chem Anal Nutr and Clin Methods. 2007;105:1536-1556.

48. Varlet V, Sérot T, Cardinal M, et al. Olfactometric determination of the most potent odor-active compounds in salmon muscle (Salmo salar) smoked by using four smoke generation techniques. J of Agri and Food Chem. 2007;55(11):4518-4525.

49. Varlet V, Sérot T, Knockaert C, et al. Organoleptic characterization and PAH content of salmon (Salmo salar) fillets smoked according to four industrial smoking techniques. $J$ of the Sci of Food and Agri. 2007;87(5):847-854

50. Varlet V, Sérot T, Monteau F, et al. Determination of PAH profiles by GC-MS/MS in salmon processed by four cold-smoking techniques. Food Additives and Contaminants. 2007;24(7):744-757.

51. Gómez Estaca J, Gómez Guillén MC, Montero P. High pressure effects on the quality and preservation of cold-smoked dolphinfish (Coryphaena hippurus) fillets. Food Chem. 2007;102(4):1250-1259.

52. Robertson CB, Andrews LS, Marshall DL, et al. Effect of X-ray irradiation on reducing the risk of listeriosis in ready-to-eat vacuumpackaged smoked mullet. J of Food Prot. 2006;69(7):1561-1564.

53. Masengi S, Shindo J, Miki H. Effect of vacuum treatment on smoke penetration into boiled skipjack loins for production of smoke-dried skipjack. Fish Sci. 2002;68:459-464.

54. Sengör GF, Kalafatoğlu H, Gün H. The determination of microbial flora, water activity and chemical analyses in smoked, canned mussels (Mytilus galloprovincialis L.). Turkish J of Veter and Animal Sci. 2004;28:793-797.

55. Munasinghe DMS, Ichimaru K, Ryuno M, et al. Lipid peroxidationderived hepatotoxic aldehydes, 4-hydroxy-2 E-hexenal in smoked fish meat products. Fish Sci. 2003;69(1):189-194

56. Lebois M, Connil N, Onno B, (2004). Effects of divercin V41 combined to $\mathrm{NaCl}$ content, phenol (liquid smoke) concentration and $\mathrm{pH}$ on Listeria monocytogenes ScottA growth in BHI broth by an experimental design approach. J of Appl Microbiol. 2004;96(5):931-937.

57. Doe PE. Fish drying. In: Bremmer HA, editor. Safety and quality issues in fish processing. Cambridge: Woodhead publishing limited; 2002. p. $350-358$.

58. Hwang CA. The probability of growth of Listeria monocytogenes in cooked salmon and tryptic soy broth as affected by salt, smoke compound, and storage temperature. Food Microbiol. 2009;26(3):253-258.

59. Goulas AE, Kontominas MG. Effect of salting and smoking-method on the keeping quality of chub mackerel (Scomber japonicus): biochemical and sensory attributes. Food Chem. 2005;93(3):511-520.

60. Sérot T, Baron R, Knockaert C, et al. Effect of smoking processes on the contents of 10 major phenolic compounds in smoked fillets of herring (Cuplea harengus). Food Chem. 2004;85(1):111-120.

61. Bakkali F, Averbeck S, Averbeck D, et al. Biological effects of essential oils-a review. Food and Chem Toxicol. 2008;46(2):446-475.

62. Burt S. Essential oils: their antibacterial properties and potential applications in foods a review. Int J Food Microbiol. 2004;94(3):223253.

63. Corrales M, Han JH, Tauscher B. Antimicrobial properties of grape seed extracts and their effectiveness after incorporation into pea starch films. Int J of Food Sci and Technol. 2009;44(2):425-433.

64. Gómez Estaca J, López de Lacey A, López Caballero ME, et al Biodegradable gelatin-chitosan films incorporated with essential oils as antimicrobial agents for fish preservation. Food Microbiol. 2010;27(7):889-896. 
65. Jang SA, Shin YJ, Song KB. Effect of rapeseed protein-gelatin film containing grapefruit seed extract on 'Maehyang' strawberry quality. Int J of Food Sci and Technol. 2011;46(3):620-625.

66. Fernandez Saiz P, Soler C, Lagaron JM, et al. Effects of chitosan films on the growth of Listeria monocytogenes, Staphylococcus aureus and Salmonella spp. in laboratory media and in fish soup. Int $J$ of Food Microbiol. 2010;137(2-3): 287-294.

67. Tsai GJ, Su WH, Chen HC, et al. Antimicrobial activity of shrimp chitin and chitosan from different treatments and applications of fish preservation. Fish Sci. 2002;68(1):170-177.

68. Fernandez Saiz P, Lagaron JM, Ocio MJ. Optimization of the biocide properties of chitosan for its application in the design of active films of interest in the food area. Food Hydrocol. 2009;23(3): 913-921.

69. Lagaron JM, Fernandez Saiz P, Ocio MJ. Using ATR-FTIR spectroscopy to design active antimicrobial food packaging structures based on high molecular weight chitosan polysaccharide. J Agri Food Chem. 2007;55(7):2554-2562.

70. Iturriaga L, Olabarrieta I, Martínez de Marañón I. Antimicrobial assays of natural extracts and their inhibitory effect against Listeria innocua and fish spoilage bacteria, after incorporation into biopolymer edible films. Int J of Food Microbiol. 2012;158(1):58-64.

71. Bagamboula CF, Uyttendaele M, Debevere J. Inhibitory effect of thyme and basil essential oils, carvacrol, thymol, estragol, linalool and p-cymene towards Shigella sonnei and S. flexneri. Food Microbiol. 2004;21(1):33-42.

72. Ilha OI, Guran HS. Combined antimicrobial effect of thymol and sodium lactate against Listeria monocytogenes and Salmonella typhimurium in fish patty. J of Food Safety. 2014;34(3):211-217.

73. Cheng C, Arritt F, Stevenson C. Controlling Listeria monocytogenes in cold smoked salmon with the antimicrobial peptide salmine. J of Food Sci. 2015;80(6):M1314-M1318.

74. Bustos CRO, Alberti RFV, Matiacevich SB. Edible antimicrobial films based on microencapsulated lemongrass oil. J Food Sci and Technol. 2016;53(1):832-839.

75. Speranza B, Bevilacqua A, Conte A, et al. Use of desirability approach to predict the inhibition of Pseudomonas fluorescens, Shewanella putrefaciens and Photobacterium phosphoreum in fish fillets through natural antimicrobials and modified atmosphere packaging. Food Bioproc Technol. 2013;6(9):2319-2330.
76. Ortiz Viedma J, Romero N, Puente L, et al. Antioxidant and antimicrobial effects of stevia (Stevia rebaudiana Bert.) extracts during preservation of refrigerated salmon paste. Eur J Lipid Sci Technol. 2017;119(10):1600467.

77. Raeisi S, Ojagh SM, Sharifi Rad M, et al. Evaluation of Allium paradoxum (M.B.) G. Don. and Eryngium caucasicum trauve. extracts on the shelf-life and quality of silver carp (Hypophthalmichthys molitrix) fillets during refrigerated storage. J Food Saf. 2017;37(3):e12321.

78. Sallam KI. Antimicrobial and antioxidant effects of sodium acetate, sodium lactate, and sodium citrate in refrigerated sliced salmon. Food Control. 2007;18(5):566-575.

79. Yoon KS, Burnette CN, Abou Zeid KA, et al. Control of growth and survival of Listeria monocytogenes on smoked salmon by combined potassium lactate and sodium diacetate and freezing stress during refrigeration and frozen storage. J Food Prot. 2004;67(11):2465-2471.

80. Vogel BF, Yin NGY, Hyldig G, et al. Potassium lactate combined with sodium diacetate can inhibit growth of Listeria monocytogenes in vacuum-packed cold smoked salmon and has no adverse sensory effects. J Food Prot. 2006;69(9):2134-2142.

81. Nes I. History, current knowledge, and future directions on bacteriocin research in lactic acid bacteria. In: Drider D, Rebuffat S, editors. Prokaryotic antimicrobial peptides: From genes to applications. New York: Springer Publishing Company; 2011. p. 3-12.

82. Ghanbari M, Jami M, Domig KJ, et al. Seafood biopreservation by lactic acid bacteria A review. LWT-Food Science and Technology. 2013;54:315-324.

83. Hall GM. Lactic acid bacteria in fish preservation. In: Bremner HA editor. Safety and quality issues in fish processing. England: Woodhead publishing limited; 2000. p. 330-347.

84. Leroi F. Occurrence and role of lactic acid bacteria in seafood products. Food Microbiol. 2010;27(6):698-709.

85. Castellano P, Gonzalez C, Carduza F, et al. Protective action of Lactobacillus curvatus CRL705 on vacuum-packaged raw beef. Effect on sensory and structural characteristics. Meat Sci. 2010;85(3):394-401.

86. Calo Mata P, Arlindo S, Boehme K, et al. Current applications and future trends of lactic acid bacteria and their bacteriocins for the biopreservation of aquatic food products. Food Bioproc Technol. 2008;1(1):43-63.

87. Leistner L. Basic Aspect of Food Preservation by Hurdle Technology. Int $J$ of Food Microbiol. 2000;55(1-3):181-186. 